\title{
Potent $\alpha$-amylase inhibitory activity of Indian Ayurvedic medicinal plants
}

Sudha $\mathrm{P}^{1 \dagger}$, Smita S Zinjarde ${ }^{1 \dagger}$, Shobha Y Bhargava ${ }^{2+}$, Ameeta R Kumar ${ }^{1{ }^{*+}}$

\begin{abstract}
Background: Indian medicinal plants used in the Ayurvedic traditional system to treat diabetes are a valuable source of novel anti-diabetic agents. Pancreatic $\alpha$-amylase inhibitors offer an effective strategy to lower the levels of post-prandial hyperglycemia via control of starch breakdown. In this study, seventeen Indian medicinal plants with known hypoglycemic properties were subjected to sequential solvent extraction and tested for $\alpha$-amylase inhibition, in order to assess and evaluate their inhibitory potential on PPA (porcine pancreatic $\alpha$-amylase). Preliminary phytochemical analysis of the lead extracts was performed in order to determine the probable constituents.

Methods: Analysis of the 126 extracts, obtained from 17 plants (Aloe vera (L.) Burm.f., Adansonia digitata L., Allium sativum L., Casia fistula L., Catharanthus roseus (L.) G. Don., Cinnamomum verum Persl., Coccinia grandis (L.) Voigt., Linum usitatisumum L., Mangifera indica L., Morus alba L., Nerium oleander L., Ocimum tenuiflorum L., Piper nigrum L., Terminalia chebula Retz., Tinospora cordifolia (Willd.) Miers., Trigonella foenum-graceum L., Zingiber officinale Rosc.) for PPA inhibition was initially performed qualitatively by starch-iodine colour assay. The lead extracts were further quantified with respect to PPA inhibition using the chromogenic DNSA (3, 5-dinitrosalicylic acid) method. Phytochemical constituents of the extracts exhibiting $\geq 50 \%$ inhibition were analysed qualitatively as well as by GC-MS (Gas chromatography-Mass spectrometry).
\end{abstract}

Results: Of the 126 extracts obtained from 17 plants, 17 extracts exhibited PPA inhibitory potential to varying degrees (10\%-60.5\%) while 4 extracts showed low inhibition (<10\%). However, strong porcine pancreatic amylase inhibitory activity (> 50\%) was obtained with 3 isopropanol extracts. All these 3 extracts exhibited concentration dependent inhibition with $I_{50}$ values, viz., seeds of Linum usitatisumum $\left(540 \mathrm{\mu gml}^{-1}\right)$, leaves of Morus alba $(1440$ $\mathrm{Mgml}^{-1}$ ) and Ocimum tenuiflorum $\left(8.9 \mathrm{gm}^{-1}\right.$ ). Acarbose as the standard inhibitor exhibited an $\mathrm{IC}_{50}$ (half maximal inhibitory concentration)value of $10.2 \mathrm{\mu gml}^{-1}$. Phytochemical analysis revealed the presence of alkaloids, tannins, cardiac glycosides, flavonoids, saponins and steroids with the major phytoconstituents being identified by GC-MS.

Conclusions: This study endorses the use of these plants for further studies to determine their potential for type 2 diabetes management. Results suggests that extracts of Linum usitatisumum, Morus alba and Ocimum tenuiflorum act effectively as PPA inhibitors leading to a reduction in starch hydrolysis and hence eventually to lowered glucose levels.

\section{Background}

DM (Diabetes mellitus) is a metabolic disorder characterized by chronic hyperglycemia or increased blood glucose levels with disturbances in carbohydrate, fat and protein metabolism resulting from absolute or relative

\footnotetext{
* Correspondence: ameeta@unipune.ac.in

+ Contributed equally

'Institute of Bioinformatics and Biotechnology, University of Pune, Pune 411 007, India

Full list of author information is available at the end of the article
}

lack of insulin secretion [1]. The frequency of this disorder is on the rise globally, is likely to hit 300 million by 2025 with India projected to have the largest number of diabetic cases [2].

Type 2 diabetes is one of the primary threats to human health due to increasing prevalence, chronic course and disabling complications [3]. Many diverse therapeutic strategies for the treatment of Type 2 diabetes are in use. The conventional available therapies for diabetes include stimulation of endogenous insulin

\section{Biomed Central}


secretion, enhancement of the action of insulin at the target tissues, oral hypoglycemic agents, such as biguanids and sulfonylureas and the inhibition of degradation of dietary starch by glycosidases such as $\alpha$-amylase and $\alpha$-glucosidase [4].

Pancreatic $\alpha$-amylase (E.C. 3.2 .1 .1 ) is a key enzyme in the digestive system and catalyses the initial step in hydrolysis of starch to a mixture of smaller oligosaccharides consisting of maltose, maltotriose, and a number of $\alpha-(1-6)$ and $\alpha-(1-4)$ oligoglucans. These are then acted on by $\alpha$-glucosidases and further degraded to glucose which on absorbtion enters the blood-stream. Degradation of this dietary starch proceeds rapidly and leads to elevated PPHG (post-prandial hyperglycemia). It has been shown that activity of HPA (human pancreatic $\alpha$-amylase) in the small intestine correlates to an increase in post-prandial glucose levels, the control of which is therefore an important aspect in treatment of type 2 diabetes [5]. Hence, retardation of starch digestion by inhibition of enzymes such as $\alpha$-amylase plays a key role in the control of diabetes. Inhibitors of pancreatic $\alpha$-amylase delay carbohydrate digestion causing a reduction in the rate of glucose absorption and lowering the post-prandial serum glucose levels [6]. Some inhibitors currently in clinical use are acarbose and miglitol which inhibit glycosidases such as $\alpha$-glucosidase and $\alpha$ amylase while others such as and voglibose inhibit $\alpha$ glucosidase. However, many of these synthetic hypoglycemic agents have their limitations, are non-specific, produce serious side effects and fail to elevate diabetic complications. The main side effects of these inhibitors are gastrointestinal viz., bloating, abdominal discomfort, diarrhea and flatulence [7]. Herbal medicines are getting more importance in the treatment of diabetes as they are free from side effects and less expensive when compared to synthetic hypoglycemic agents $[8,9]$.

In India, indigenous herbal remedies such as Ayurveda and other Indian traditional medicine have since ancient times used plants in treatment of diabetes [10]. Ethnobotanical studies of traditional herbal remedies used for diabetes have identified more than 1,200 species of plants with hypoglycemic activity $[3,11]$. A number of medicinal plants and their formulations are used for treating diabetes in the traditional Indian Ayurvedic system as well as in ethnomedicinal practices. Even though, these traditional practices are empirical in nature, over 200 million people in India with limited access to primary healthcare centres, depend on traditional system of medicine to cater to their healthcare needs [12]. However, this traditional knowledge, derived empirically, has to be supported by scientific testing. WHO (World Health Organization) (1980) has recommended the evaluation and mechanistic properties of the plants effective in such systems $[13,14]$.
The search for new pharmacologically active agents obtained by screening natural sources such as medicinal plants or their extracts can lead to potent and specific inhibitors for $\alpha$-amylase [6]. Pharmacological properties $\alpha$-glucosidase inhibitors such as acarbose that can also inhibit pancreatic $\alpha$-amylase revealed that the complications of DM such as onset of renal, retinal, lens and neurological changes and the development of ischaemic myocardial lesions are prevented or delayed [15]. Long-term day-to-day management of diabetes, with acarbose is well tolerated and can improve glycaemic control as monotherapy, as well as in combination therapy [16].

The Western Ghat area in the western region of India was declared an ecological hotspot in 1988 by the Government of India. Though this area covers barely five percent of India's land, $27 \%$ of all species of higher plants in India are found here. Some plants found here such as Aloe vera (L.) Burm.f., Adansonia digitata L., Allium sativum L., Casia fistula L., Catharanthus roseus (L.) G. Don., Cinnamomum verum Persl., Coccinia grandis (L.) Voigt., Linum usitatisumum L., Mangifera indica L., Morus alba L., Nerium oleander L., Ocimum tenuiflorum L., Piper nigrum L., Terminalia chebula Retz., Tinospora cordifolia (Willd.) Miers., Trigonella foenum-graceum L., Zingiber officinale Rosc. are well known in Ayurveda to possess anti-diabetic properties [8,9,17-21]. These plants are known to lower blood glucose levels and their traditional uses are listed in Table 1. So far, reports on the systematic evaluation and scientific investigation of these antdiabetic plants or their phytoconstituents pancreatic $\alpha$-amylase inhibitors are scarce. This study was carried out not only to validate the traditional uses of these plants in diabetes but also to initiate search for newer pharmacophores with specificity towards pancreatic $\alpha$-amylase. Structurally as well as mechanistically, PPA (Porcine pancreatic $\alpha$-amylase) is closely related to HPA (Human pancreatic $\alpha$-amylase) [22]. Hence, sequential solvent extracts of the abovementioned plants were screened for the presence of PPA inhibitors, the lead extracts quantified for PPA inhibition under in vitro conditions and subjected to phytochemical analysis in order to identify the probable inhibitory phytoconstituents.

\section{Methods \\ Material}

Chemicals such as soluble starch, PPA (porcine pancreatic $\alpha$-amylase), methanol, isopropanol, acetone, methylbutyl-tertiary ether, cyclohexane and DMSO (dimethylsulfoxide) were purchased from SRL Pvt. Ltd, Mumbai, India. DNSA (3, 5-dinitrosalicylicacid) was obtained from HiMedia Laboratories, Mumbai, India. Acarbose 
Table 1 Plant sources and their traditional uses

\begin{tabular}{|c|c|c|c|c|}
\hline Plants Name & Family & $\begin{array}{l}\text { Parts } \\
\text { used }\end{array}$ & Hypoglycemic and medicinal properties & Ref. \\
\hline Adansonia digitata $L$. & Bombacaceae & Leaves & $\begin{array}{l}\text { Lowers blood glucose level due to insulin like effect on peripheral tissues; by } \\
\text { promoting glucose uptake and metabolism or by inhibiting hepatic } \\
\text { gluconeogenesis }\end{array}$ & [18] \\
\hline Allium sativum $L$. & Alliaceae & Rhizomes & $\begin{array}{l}\text { Lowers blood pressure and improves lipid profile, decreases serum glucose, } \\
\text { triglycerides, cholesterol, urea, uric acid, increases serum insulin levels }\end{array}$ & [40] \\
\hline Aloe vera (L.) Burm.f. & Liliace & Leaf Gel & $\begin{array}{l}\text { Hypoglycemic activity, decreases fasting glucose levels, hepatic transaminases, } \\
\text { plasma and liver cholesterol, triglycerides, free fatty acids and phospholipids. } \\
\text { Improves plasma insulin level. Restores normal levels of LDL and HDL and } \\
\text { cholesterol Reduces levels of hepatic phosphatidylcholine hydroperoxide and } \\
\text { have hypocholesterimic efficacy, diminishes degenerative changes observed in } \\
\text { kidney tissues }\end{array}$ & [41] \\
\hline Casia fistula L. & Caesalpiniaceae & Leaves & Hypoglycemic activity decreases blood glucose level & [19] \\
\hline Catharanthus roseus (L.). G. Don & Apocynaceae & Leaves & $\begin{array}{l}\text { Reduces blood glucose by enhancing secretion of insulin from } \beta \text {-cells of } \\
\text { Langerhans or through extra pancreatic mechanism }\end{array}$ & [42] \\
\hline Cinnamomum verum Persl. & Lauraceae & Bark & Reduces the blood glucose and elevates the plasma insulin level. & [43] \\
\hline Coccinia grandis (L.) Voigt. & Cucurbitacea & Fruit & $\begin{array}{l}\text { Reduces blood glucose and glycosylated hemoglobin content. C. indica } \\
\text { extracts lowers blood glucose by depressing its synthesis, depression of } \\
\text { glucose 6-phosphatase and fructose1,6, bisphosphatase and enhancing glucose } \\
\text { oxidation by shunt pathway through activation of iglucose 6-phosphate } \\
\text { dehydrogenase }\end{array}$ & [44] \\
\hline Linum usitatisumum L. & Linaceae & Seeds & $\begin{array}{l}\text { Reduces fasting blood sugar levels, total cholesterol; reduces carbohydrate } \\
\text { absorption from gut and clinical symptoms of diabetes associated with } \\
\text { dyslipidamia. }\end{array}$ & {$[20]$} \\
\hline Mangifera indica $L$. & Anacardiaceae & $\begin{array}{l}\text { Fruit, } \\
\text { Leaves }\end{array}$ & $\begin{array}{l}\text { Reduces glucose absorption in type } 2 \text { diabetes. Stimulates glycogenesis in liver } \\
\text { causing reduction in blood glucose level. }\end{array}$ & [45] \\
\hline Morus alba L. & Moraceae & Leaves & $\begin{array}{l}\text { Antiphlogistic, diuretic, expectorant and antidiabetic. Increases the } \beta \text {-cell } \\
\text { number in diabetic islets. Reduces levels of glycosylated hemoglobin. } \\
\text { Decreases triglycerides, cholesterol and VLDL to normal levels in type II DM } \\
\text { patients. Restores elevated levels of blood urea. }\end{array}$ & [46] \\
\hline Nerium oleander $L$. & Apocynaceae & Leaves & $\begin{array}{l}\text { Clorogenic acid, querecetin and cathechin induce post prandial hyperglycemia } \\
\text { by acting as } \alpha \text {-glucosidase inhibitors. }\end{array}$ & [21] \\
\hline Ocimum tenuiflorum $L$. & Laminaceae & Leaves & $\begin{array}{l}\text { Lowers blood glucose level, modulates cellular antioxidant defense system. } \\
\text { Improves } \beta \text { cell function and enhances insulin secretion. Inhibits absorption of } \\
\text { glucose from the intestine }\end{array}$ & [47] \\
\hline Piper nigrum L. & Piperaceae & Seeds & Reduces glucose and serum lipid levels & [48] \\
\hline Terminalia chebula Retz. & Combretaceae & Fruit & $\begin{array}{l}\text { Decreases blood glucose levels by enhancing secretion of insulin from } \beta \text { cells } \\
\text { of Langerhans or through extra pancreatic mechanism. Inhibits advanced } \\
\text { glycosylation end products, which contribute to renal damage. }\end{array}$ & [49] \\
\hline Tinospora cordifolia (Willd.) Miers & Menispermaceae & Stem & $\begin{array}{l}\text { Decreases blood glucose level through glucose metabolism. It exhibits } \\
\text { inhibitory effect on adrenaline-induced hyperglycemia. }\end{array}$ & [50] \\
\hline Trigonella foenum-graceum $L$. & Fabaceae & Seeds & Decreases s post prandial blood glucose level. & [51] \\
\hline Zingiber officinale Rosc. & Zingiberaceae & Rhizome & Lowers plasma glucose level & {$[52]$} \\
\hline
\end{tabular}

was purchased from Sigma Aldrich, USA. All other chemicals procured were from local manufacturer and were of AR grade.

\section{Plant material}

The above mentioned anti-diabetic plants were collected from the Western Ghats, Maharashtra State, India in the months of August-January. Herbarium specimen of each these plants was submitted to Botanical Survey of India, Pune for authentication. The voucher numbers are specified in additional file 1. Plant name, family, parts used along with its hypoglycemic and medicinal properties are listed in Table 1.

\section{Preparation of plant extracts}

Air-dried plant material was finely crushed, powdered and successively extracted in polar to non-polar solvent on an increasing degree of non-polarity. The solvents used in sequential order were cold water, hot water, methanol, isopropanol, acetone, methyl-butyl-tertiary ether and cyclohexane. The significance of sequential extraction from polar to non-polar solvent is the fact that traditional Ayurvedic methods of preparing herbal formulations are mainly aqueous. It is also likely that peptides, proteins or glycans possessing $\alpha$-amylase inhibitory activity would be extracted in aqueous system which would otherwise be denatured during organic 
solvent and high temperature extraction. Cold and hot water extracts were obtained by adding water to the crushed material in a ratio of $1: 4(\mathrm{w} / \mathrm{v})$ and kept at $30^{\circ} \mathrm{C}$ $(24 \mathrm{~h})$ and $55^{\circ} \mathrm{C}(2 \mathrm{~h})$ at130 $\mathrm{rpm}$ respectively. Each of the extract was filtered, centrifuged and the residue collected was subjected to subsequent solvent extraction. The organic solvents were added in a ratio of $1: 3(\mathrm{w} / \mathrm{v})$ and refluxed with the residue for $3 \mathrm{~h}$ at their respective boiling temperatures. The extracts collected were filtered and stored at $-20^{\circ} \mathrm{C}$. Before assay, the organic filtrates were concentrated in vacuo in a rotary evaporator at $50^{\circ} \mathrm{C}$ while the aqueous extracts were lyophilized. Stock solutions for inhibition assay were prepared by dissolving up to $1.5 \mathrm{mg}$ of each extract in $1 \mathrm{ml}$ of DMSO and appropriately diluting it before use.

\section{Pancreatic $\alpha$-amylase inhibition assays Starch-lodine colour assay}

Screening of plant material for $\alpha$-amylase inhibitors was carried out in a microtitre plate according to Xiao et al (2006) based on the starch-iodine test [23]. The total assay mixture composed of $40 \mu \mathrm{l} 0.02 \mathrm{M}$ sodium phosphate buffer ( $\mathrm{pH} 6.9$ containing $6 \mathrm{mM}$ sodium chloride), 0.02 units of PPA solution and plant extracts at concentration from $0.1-1.5 \mathrm{mgml}^{-1}(\mathrm{w} / \mathrm{v})$ were incubated at $37^{\circ} \mathrm{C}$ for $10 \mathrm{~min}$. Then soluble starch $(1 \%$, w/v) was added to each reaction well and incubated at $37^{\circ} \mathrm{C}$ for 15 min. $1 \mathrm{M} \mathrm{HCl}(20 \mu \mathrm{l})$ was added to stop the enzymatic reaction, followed by the addition of $100 \mu \mathrm{l}$ of iodine reagent ( $5 \mathrm{mM} \mathrm{I}_{2}$ and $5 \mathrm{mM} \mathrm{KI}$ ). The colour change was noted and the absorbance was read at 620 $\mathrm{nm}$ on a microplate reader. The control reaction representing $100 \%$ enzyme activity did not contain any plant extract. To eliminate the absorbance produced by plant extract, appropriate extract controls without the enzyme were also included. The known PPA inhibitor, acarbose, was used a positive control at a concentration range of $6.5-32.8 \mu \mathrm{gml}^{-1}$. A dark-blue colour indicates the presence of starch; a yellow colour indicates the absence of starch while a brownish colour indicates partially degraded starch in the reaction mixture. In the presence of inhibitors from the extracts the starch added to the enzyme assay mixture is not degraded and gives a darkblue colour complex whereas no colour complex is developed in the absence of the inhibitor, indicating that starch is completely hydrolysed by $\alpha$-amylase.

\section{3, 5-dinitrosalicylic acid assay}

The inhibition assay was performed using the chromogenic DNSA method [24]. The total assay mixture composed of $500 \mu \mathrm{l}$ of $0.02 \mathrm{M}$ sodium phosphate buffer (pH 6.9 containing $6 \mathrm{mM}$ sodium chloride), 0.04 units of PPA solution and extracts at concentration from $0.1-1.5 \mathrm{mgml}^{-1}(\mathrm{w} / \mathrm{v})$ were incubated at $37^{\circ} \mathrm{C}$ for 10 min. After pre-incubation, $500 \mu \mathrm{l}$ of $1 \%(\mathrm{v} / \mathrm{v})$ starch solution in the above buffer was added to each tube and incubated at $37^{\circ} \mathrm{C}$ for $15 \mathrm{~min}$. The reaction was terminated with $1.0 \mathrm{ml}$ DNSA reagent, placed in boiling water bath for $5 \mathrm{~min}$, cooled to room temperature, diluted and the absorbance measured at $540 \mathrm{~nm}$. The control PPA at $0.21 \mathrm{Uml}^{-1}$ represented $100 \%$ enzyme activity and did not contain any plant extract. To eliminate the absorbance produced by plant extract, appropriate extract controls with the extract in the reaction mixture except for the enzyme were also included. The known PPA inhibitor acarbose was used a positive con-

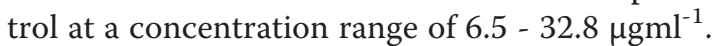

One unit of enzyme activity is defined as the amount of enzyme required to release one micromole of maltose from starch per min under the assay conditions.

The $\mathrm{IC}_{50}$ values were determined from plots of percent inhibition versus log inhibitor concentration and calculated by logarithmic regression analysis from the mean inhibitory values. The $\mathrm{IC}_{50}$ values were defined as the concentration of the extract, containing the $\alpha$-amylase inhibitor that inhibited $50 \%$ of the PPA activity.

The other quantifiers were calculated as follows:

$\%$ Relative enzyme activity $=($ enzyme activity of test $/$ enzyme activity of control $) * 100$.

$\%$ inhibition in the $\alpha$ - amylase activity $=(100-\%$ relative enzyme activity $)$.

\section{Preliminary Phytochemical Analysis}

The lead extracts were subjected to qualitative phytochemical analysis while the identification of the major phytoconstituents was carried out using GC-MS.

\section{Qualitative phytochemical analysis}

Lead extracts positive for $\alpha$-amylase inhibition were tested for the presence of proteins, alkaloids, tannins, saponins, cardiac glycosides, steroids and flavonoids in accordance to Parekh and Chanda and Trease and Evans (1989) [25,26].

\section{GC-MS Analysis}

Analysis of the lead organic extracts exhibiting $\geq 50 \%$ inhibition on the PPA activity were performed on a GCMS-MS (HEWLETT PACKARD, GCD-1800 A) gas chromatograph equipped with DB 5 ms capillary column $(30 \mathrm{~m} \times 0.25 \mathrm{~mm}$ ID). Helium was the carrier gas with flow rate of $1 \mathrm{~mL} / \mathrm{min}$, the injector mode- split (1:60), the injection volume $1 \mu \mathrm{L}$, the temperature program used is as follows: $80^{\circ} \mathrm{C}(3 \mathrm{~min})$, then increased to $280^{\circ} \mathrm{C}$ at $10^{\circ} \mathrm{C} / \mathrm{min}$, held at $280^{\circ} \mathrm{C}(10 \mathrm{~min})$ and temperature scan, $m / z$ 35-300 amu. Appropriate solvent controls were also run. The identification of the components was based on the comparison of their mass spectra with those of NIST-Wiley 2008 library.

\section{Statistical Data Analysis}

All experiments were performed in 3 different sets with each set in triplicates. The data are expressed as mean \pm 
SEM (standard error of the mean). Statistical analysis was performed for ANOVA (analysis of variance) followed by $\mathrm{F}$ test using SPSS version 11.5. Values of $\mathrm{p}$ which were $\leq 0.05$ were considered as significant.

\section{Results and Discussion}

Drugs that reduce post-prandial hyperglycaemia by suppressing hydrolysis of starch such as PPA inhibitors have been found useful in the control of diabetes mellitus $[27,28]$. Many herbal extracts have been reported for their anti-diabetic activities and are currently being used in Ayurveda for the treatment of diabetes. However, such medicinal plants have not gained much importance as medicines due to the lack of sustained scientific evidence.

In the present study, seventeen indigenous antidiabetic medicinal plants from the Western Ghats of India were screened for their $\alpha$-amylase inhibitory potential. Plants used in the study along with the parts used and their hypoglycemic properties are listed in Table 1 while their voucher numbers are listed as an additional file 1 . Several studies performed on these plants state them to be hypoglycemic, but none of these plants have been studied or tested for pancreatic $\alpha$-amylase inhibitors in order to justify their hypoglycemic property. The rationale for performing extractions from polar to non-polar solvents is to confirm and validate the inhibitory activity in the aqueous extractions performed in the traditional manner as well as to search for newer, more potent inhibitory compounds in the organic solvents. Primary screening for $\alpha$-amylase inhibition was performed based on starch-iodine colour complex formation. Upon extraction a total of 126 extracts were obtained from 17 plants. Of these 126 extracts screened, 21 extracts tested positive for PPA inhibition (Table 2). These lead extracts were further quantified with respect to PPA inhibition by chromogenic DNSA method and it was noted that 4 extracts exhibited low $(<10 \%)$ while 17 extracts showed significant ( $p$ value $\leq 0.05)$ PPA inhibitory activity $(10-60.5 \%)$.

The aqueous extracts, i.e., cold water extracts of A. vera, and T. foenum exhibited $23.3 \%$, and $13.4 \%$ inhibition at concentration of $2.5 \mathrm{mgml}^{-1}$ and $1.5 \mathrm{mgml}^{-1}$ respectively. Low inhibitory potential ( $p$ value $\leq 0.1$ ) was observed for hot water extracts of T. foenum (10.8\%) at a concentration of $3.5 \mathrm{mgml}^{-1}$. Methanol extracts of C. fistula showed 29.2\% PPA inhibition followed by M. alba (15.1\%) and T. foenum (11.8\%) at $1.9 \mathrm{mgml}^{-1}$, $3.9 \mathrm{mgml}^{-1}$ and $5.2 \mathrm{mgml}^{-1}$, respectively. Significant $(p<$ 0.05 ) and strong PPA inhibition was observed for isopropanol extracts of $M$. alba (60.5\%)at $1.8 \mathrm{mgml}^{-1}$, L. usitatisumum $(55.7 \%)$ at $0.65 \mathrm{mgml}^{-1}$ and O. tenuiflorum $(53.4 \%)$ at $0.0094 \mathrm{mgml}^{-1}$ whereas low inhibition was noted in the case of C. fistula (10.0\%) at $2.4 \mathrm{mgml}^{-1}$
Table 2 Inhibition of PPA activity based on starch-iodine color assay by solvent extracts ${ }^{a}$ of different plants at 0.1-1.5 $\mathrm{mgml}^{-1}(\mathrm{w} / \mathrm{v})$

\begin{tabular}{|c|c|c|c|c|c|c|c|}
\hline \multirow[t]{2}{*}{ Plant Species } & \multicolumn{7}{|c|}{ Extracts } \\
\hline & CWE & HWE & ME & IPE & $\mathrm{AE}$ & MTBE & $\mathrm{CHE}$ \\
\hline A. digitata (Leaves) & - & - & - & - & - & - & - \\
\hline A. sativum (Rhizomes) & - & - & - & - & - & - & - \\
\hline A. vera (Leaf Gel) & + & - & - & - & - & - & + \\
\hline C. fistula (Leaves) & + & + & + & + & - & + & + \\
\hline C. roseus (Leaves) & - & - & - & - & - & - & - \\
\hline C. verum (Bark) & - & - & - & - & - & - & - \\
\hline C. indica. (Fruit) & - & - & - & - & - & - & - \\
\hline L. usitatisumum (Seeds) & - & - & - & + & + & + & - \\
\hline M. indica (Leaves) & - & - & - & - & - & - & - \\
\hline M. indica (Fruit) & - & - & - & - & - & - & - \\
\hline M. alba (Leaves) & - & - & + & + & - & - & - \\
\hline N. indicum (Leaves) & - & - & - & - & - & - & - \\
\hline O. tenuiflorum (Leaves) & - & - & - & + & - & - & - \\
\hline P. nigrum (Seed) & - & - & - & - & - & - & - \\
\hline T. chebula (Fruit) & - & - & - & - & - & - & - \\
\hline T. cordifolia (Stem) & - & - & - & - & - & - & - \\
\hline T. foenum (Seeds) & + & + & + & + & + & + & + \\
\hline Z. officinallis (Rhizomes) & - & - & - & - & - & - & - \\
\hline Acarbose $\left(6.5-32.8 \mu_{\mathrm{gml}^{-1}}\right)$ & + & & & & & & \\
\hline
\end{tabular}

${ }^{a}$ Extracts were sequentially prepared as described in Methods.

+ : Inhibition.

-: No Inhibition.

CWE: Cold water Extract.

HWE: Hot water Extract.

ME: Methanol Extract.

IPE: Isopropanol Extract.

AE: Acetone Extract.

MTBE: Methyl-tertiary-butyl Ether Extract.

CHE: Cyclohexane Extract.

and T. foenum (13.2\%) at $3.6 \mathrm{mgml}^{-1}$. Acetone extracts of L. usitatisumum (33.5\%) exhibited moderate PPA inhibition ( $p$ value $\leq 0.05)$ at a concentration of $2.6 \mathrm{mgml}^{-1}$. Methyl-tertiary-butyl ether extracts of C. fistula (18.9\%) and L. usitatisumum (39.1\%) showed PPA inhibitory activity at $3.4 \mathrm{mgml}^{-1}$ and $2.7 \mathrm{mgml}^{-1}$, while cyclohexane extracts of C. fistula (25.2\%), T. foenum (19.3\%) and A. vera (15.8\%) also showed moderate PPA inhibitory activity at $5.7 \mathrm{mgml}^{-1}, 1.9 \mathrm{mgml}^{-1}$ and $2.4 \mathrm{mgml}^{-1}$, respectively ( $p$ value $\leq 0.1$ ) (Figure 1 ). All the other extracts showed no significant PPA inhibitory activity (Table 2, Figure 1). None of the extracts were found to enhance PPA activity.

Thus of the abovementioned extracts only three viz; L. usitatisumum, M. alba and, O. tenuiflorum isopropanol extracts exhibited strong i.e., $\geq 50 \%$ inhibition against PPA. Concentration dependent incubation of these isopropanol plant extracts of L. usitatisumum $\left(0.5-2.6 \mathrm{mgml}^{-1}\right)$, M. alba (0.3-1.8 $\left.\mathrm{mgml}^{-1}\right)$ and O. tenuiflorum (0.001$\left.0.009 \mathrm{mgml}^{-1}\right)$, respectively with $\alpha$-amylase and starch 


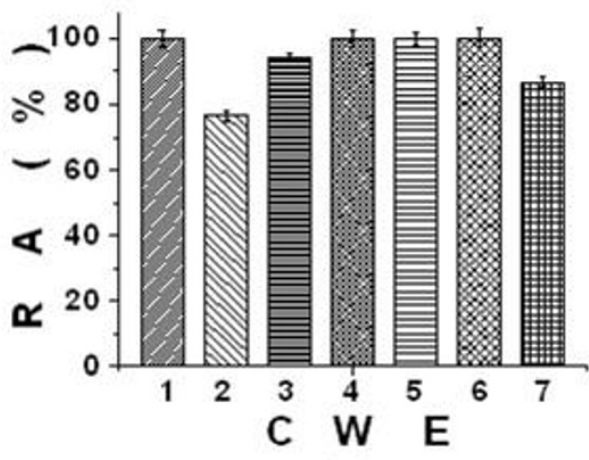

(a)

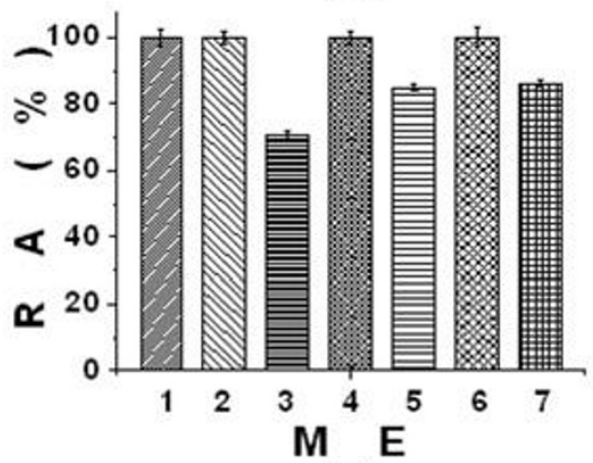

(c)

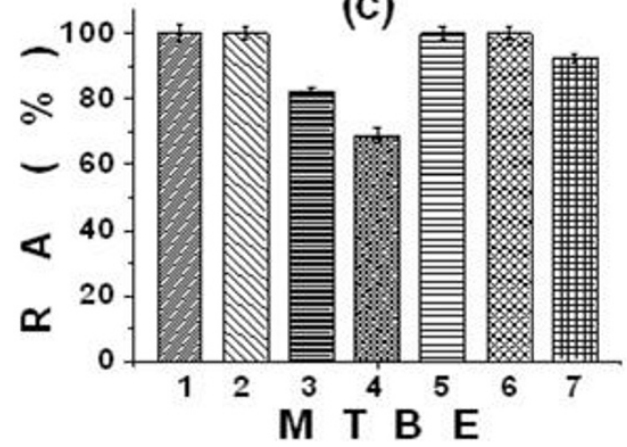

(e)

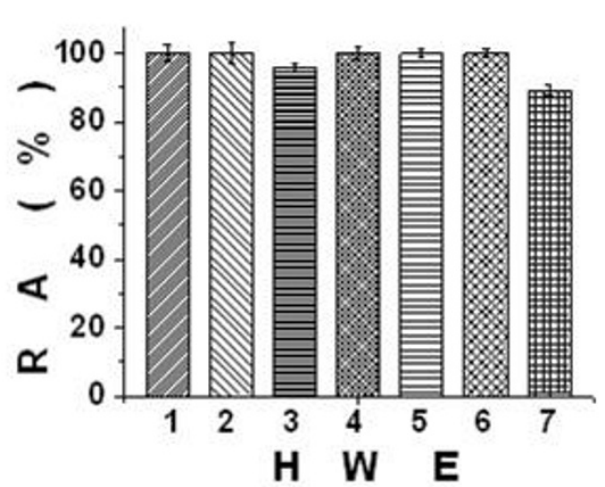

(b)

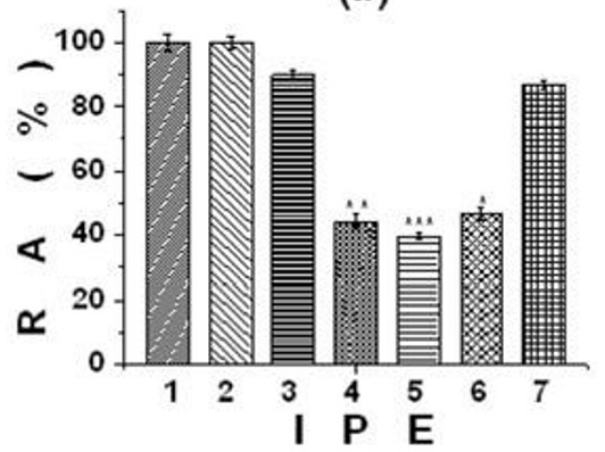

(d)

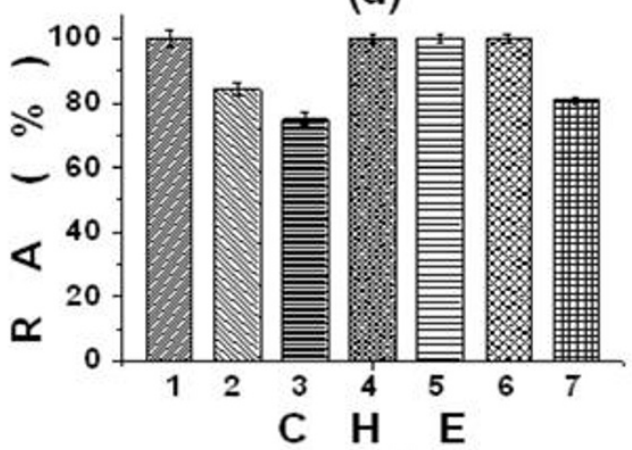

(f)

Figure 1 The percent relative enzyme activity (RA \%) of porcine pancreatic $\alpha$-amylase (PPA) on inhibition with different extracts. (a) Cold water extracts-CWE (b) Hot water extracts-HWE (c) Methanol extracts-ME (d) Isopropanol extracts-IPE (e) Methyl-tertiary-butyl-ether extactsMTBE $(f)$ Cyclohexane extracts-CHE of the listed plants. Pure porcine pancreatic $\alpha$-amylase serves as control. The data is indicated as the mean \pm SEM; $(n=3)$. The students F-test was used and the bars with different asterisks $(* * *, * *, *)$ show significant difference with respect to control $(P<$ 0.05). 1 Control 2 A. vera 3 C. fistula 4 L. usitatisumum 5 M. alba 6 O. tenuiflorum 7 T. foenum.

in vitro resulted in a significant $(p \leq 0.05)$ decrease in the enzyme activities from $0.21 \mathrm{U}$ to $0.09 \mathrm{U}$. A dose dependent effect was observed on increasing the concentrations of the extract solution, suggesting a competitive type of inhibition. Plots of percent inhibition vs log concentration of extracts showed typical sigmoidal dose response curves (Figure 2). It was noted that the $\mathrm{IC}_{50}$, values i.e., $50 \%$ inhibition occurred at concentrations of $540 \mu \mathrm{gml}^{-1}, 1440 \mu \mathrm{gml}^{-1}, 8.9 \mu \mathrm{gml}^{-1}$ for L. usitatisumum, M. alba, O. tenuiflorum, respectively. Acarbose was taken as a positive control with an $\mathrm{IC}_{50}$ value at $10.2 \mu \mathrm{gml}^{-1}$. O. tenuiflorum isopropanol extract exhibited an $\mathrm{IC}_{50}$ value less than acarbose suggesting that it could be a promising lead extract.

It could thus be speculated that these 3 extracts possess significant PPA inhibiting activity. Phytochemical analysis of these isopropanol extracts revealed the presence of alkaloids, steroids, saponins and cardiac glycosides in L. usitatisumum. Tannins, cardiac glycosides, flavonoids and saponins were detected in $M$. alba 


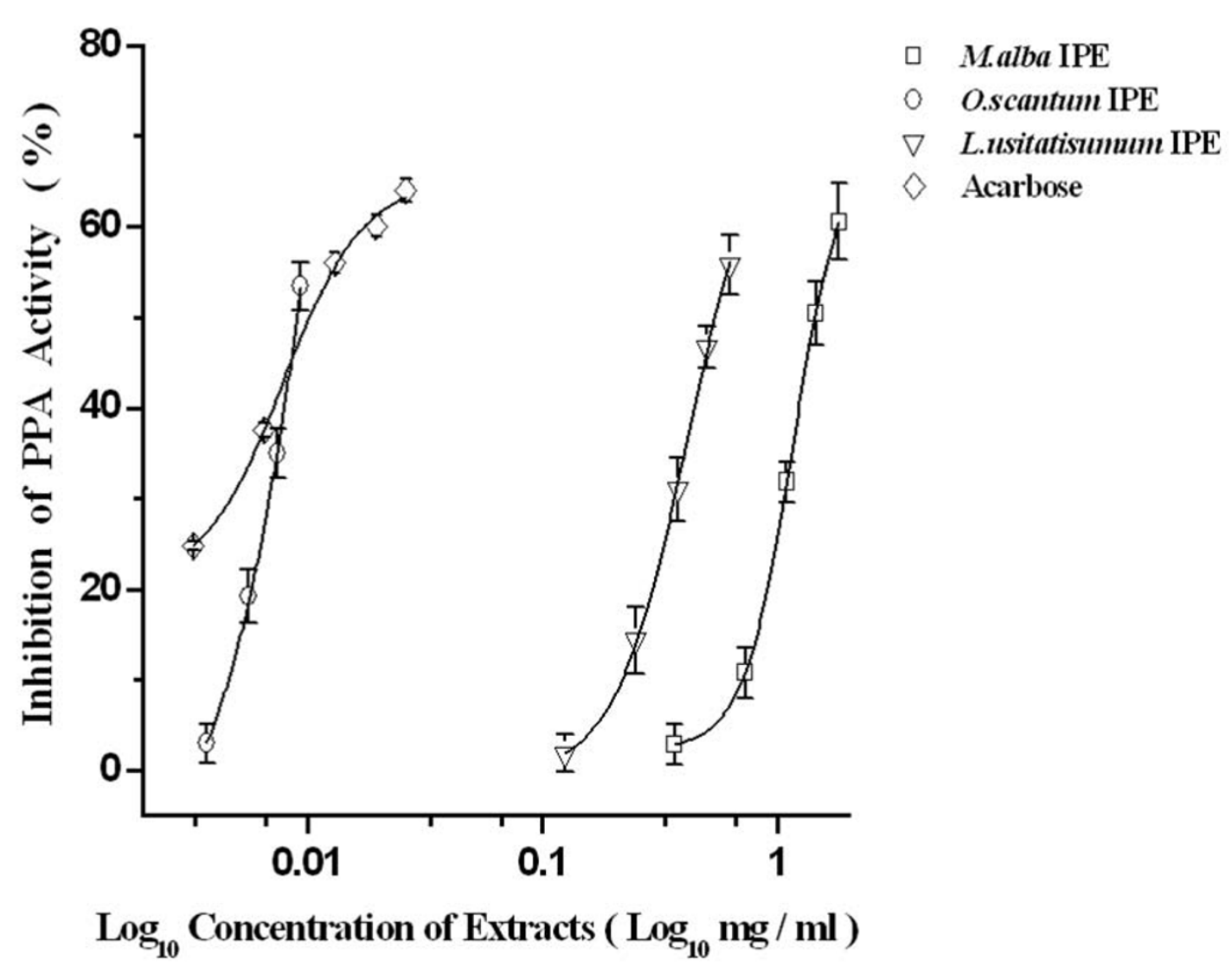

Figure 2 The percent Porcine Pancreatic $\alpha$-amylase inhibition (\%) of different extracts at varying concentrations. The data is indicated as the mean \pm SEM; $(n=3)$. $(P<0.05)$. IPE - Isopropanol Extract.

while $O$. tenuiflorum extract was found to contain alkaloids, tannins and flavonoids (Table 3).

Preliminary GC-MS analysis based on retention time and molecular mass was performed to determine the nature of these phytoconstituents (Table 4). It was noted that in $L$. usitatisumum seed isopropanol extract the major compound detected could either be 2-cyclopentene-1-undecanoic acid (hydnocarpic acid) or

Table 3 Qualitative phytochemical analysis of isopropanol extracts exhibiting $\geq \mathbf{5 0} \%$ inhibition on PPA activity

\begin{tabular}{lccc}
\hline Plant Species & L. usitatisumum & M. alba & O. tenuiflorum \\
\hline Proteins & - & - & - \\
Alkaloids & + & - & + \\
Tannins & - & + & + \\
Cardic glycosides & + & + & - \\
Flavinoids & - & + & + \\
Saponins & + & + & - \\
Steroids & + & - & - \\
\hline
\end{tabular}

+ Detected.

- Not detected. cyclopentane undecanoic acid (dihydrohydnocarpic acid). The other compounds were in too low a concentration to be correctly identified. Such natural cyclic fatty acids are found in seeds from species of plants belonging to Flacourtiaceae family [29]. It has also been suggested that on heating of vegetal oils several fatty acids containing cyclopentnyl or cyclohexanyl ring are formed from linoleic and linolenic acids [30], under conditions similar to those used for solvent extraction. It has also been shown that compounds like linoleic and $\alpha$-linoleic acids as well as lignin glycosides are present in L. usitatisumum seeds [31]. In our previous report, we have shown that Linum usitatissimum extract could significantly inhibit crude preparations of glycosidases isolated from murine pancreas but not from the liver or small intestines [32]. Hence, this extract seems to possess potential PPA inhibitory activity and could be a good candidate to carry out further in vivo studies.

The major phytoconstituents detected in the leaf isopropanol extract of $M$. alba were naphthalene, hexadeconoic (palmitic acid) and 9, 12-octadecadienoic acid (9,12-linoleic acid). These compounds have also been detected in M.alba leaves by earlier researchers [33]. 
Table 4 GCMS Profile of extracts exhibiting $\geq 50 \%$ inhibition on PPA activity

\begin{tabular}{|c|c|c|c|c|c|}
\hline Name of the plant & Name of the compound & $\begin{array}{c}\text { Molecular } \\
\text { formula }\end{array}$ & $\begin{array}{c}\text { Molecular } \\
\text { weight }\end{array}$ & $\begin{array}{c}\text { Area } \\
(\%)\end{array}$ & $\begin{array}{l}\text { Retention time } \\
\text { (min) }\end{array}$ \\
\hline \multirow[t]{3}{*}{ O. tenuiflorum } & Camphene & $\mathrm{C}_{10} \mathrm{H}_{16}$ & 136.24 & 32.42 & 9.83 \\
\hline & Methyleugenol & $\mathrm{C}_{11} \mathrm{H}_{14} \mathrm{O}_{2}$ & 178.23 & 37.87 & 10.82 \\
\hline & 2-heptanol, 5-ethyl & $\mathrm{C}_{9} \mathrm{H}_{20} \mathrm{O}$ & 144.25 & 9.44 & 11.04 \\
\hline \multirow[t]{3}{*}{ M. alba } & Napthelene & $\mathrm{C}_{10} \mathrm{H}_{8}$ & 128.6 & 28.36 & 11.12 \\
\hline & Hexadeconoic acid & $\mathrm{C}_{16} \mathrm{H}_{32} \mathrm{O}_{2}$ & 256.4 & 40.76 & 14.23 \\
\hline & 9,12 -octadecadienic acid & $\mathrm{C}_{17} \mathrm{H}_{31} \mathrm{COOH}$ & 280.44 & 9.32 & 13.92 \\
\hline L. usitatisumum & $\begin{array}{l}\text { 2-cyclopentene-1-undecanoic } \\
\text { acid/ } \\
\text { cyclopentane undecanoic acid }\end{array}$ & $\begin{array}{l}\mathrm{C}_{16} \mathrm{H}_{28} \mathrm{O}_{2} \\
\mathrm{C}_{16} \mathrm{H}_{30} \mathrm{O}_{2}\end{array}$ & $\begin{array}{l}252 \\
/ \\
254\end{array}$ & 85.6 & 21.03 \\
\hline
\end{tabular}

Wei Song et al reported the presence of oxyresveratrol and 1-DNJ (1-deoxynojirimycin) in methanol extracts of M.alba leaves from China. 1-DNJ is a known inhibitor of $\alpha$-glucosidase and $\alpha$-amylase [34]. However, the methanol extract in our study showed relatively low PPA inhibitory activity (15.1\%) as compared to the isopropanol extract (60.5\%).

The major compounds identified from the leaf extract of O. tenuiflorum, were camphene, methyleugenol and 2-heptanol, 5-ethyl-. These monoterpenes, phenyl propanoids and alcohols have been reported earlier from Ocimum sp. [35-37]. Oral administration of ethanolic extracts of $O$. tenuiflorum were found to reduce serum glucose levels in normal and streptozotocin induced diabetic rats [38]. Essential oils obtained from Cedrus libani were found to inhibit $\alpha$-amylase activity with an $\mathrm{IC}_{50}$ value of $0.14 \mathrm{mg} / \mathrm{ml}$ [39]. One of the compounds in this oil was identified as camphene, similar to that detected in O. tenuiflorum. Our earlier study [32] has also shown that $O$. tenuiflorum extracts possessed significant inhibitory activity against isolated glycosidase preparations obtained from murine pancreatic, liver and small intestinal tissues.

These findings suggest that one of the mechanisms by which L. usitatisumum, M. alba and O. tenuiflorum could be exhibiting their hypoglycemic effect would be by inhibition of PPA activity leading to retardation of starch hydrolysis, eventually lowering PPHG. All the phytoconstituents have earlier been reported from these plants but none of them have shown to possess PPA inhibitory activity. Since, the nature of the phytochemical responsible for PPA inhibitory activity has not yet been ascertained, the active principle(s) needs to be isolated and characterized through in vitro and in vivo studies. While some anti-diabetic plants in this study showed negligible inhibition against PPA, 17 extracts exhibited moderate to good enzyme inhibitory activity. Hence, though multiple mechanisms exist by which these plants could affect their hypoglycemic potential, one of the mechanisms by which some of these plants could be lowering PPHG levels could be due to PPA inhibition.

\section{Conclusions}

Since the Indian population has long been using all the 3 plants for food and medicinal purposes, they form a part of the local pharmacopoeia. Our results suggest that one of the targets for hypoglycaemic property of L. usitatisumum, M. alba and O. tenuiflorum is pancreatic $\alpha$-amylase inhibition. However, isolation and characterization of the compounds responsible for this inhibitory activity as well as in vivo studies need to be performed to confirm these observations. These phytochemical(s)/bioactive principle from the plants responsible for the PPA inhibition are currently being isolated and characterized.

\section{Additional material}

Additional file 1: Plant Names and the Botanical Survey of India (BSI), Pune Voucher Numbers.

\section{Acknowledgements}

The work was supported by UGC (University Grants Commission), New Delhi. SP was the recipient of financial aid provided by UGC. The authors thank the Botany Department, University of Pune for their help in procuring the plant samples and The BSI (Botanical Survey of India), Pune for authentication of the collected plant samples.

\section{Author details}

${ }^{1}$ Institute of Bioinformatics and Biotechnology, University of Pune, Pune 411 007, India. ${ }^{2}$ Molecular Embryology Laboratory, Department of Zoology, University of Pune, Pune 411 007, India.

\section{Authors' contributions}

SP performed the experiments as a part of her doctoral work. SSZ helped in the collection of samples and in their authentication. SB participated in the statistical analysis of the data and helped to draft the manuscript. All this work was carried out under the supervision of ARK who conceived and coordinated the study, designed the experiments and helped to draft the manuscript. All the authors have read and approved the final manuscript. 


\section{Competing interests}

The authors declare that they have no competing interests

Received: 19 August 2010 Accepted: 20 January 2011

Published: 20 January 2011

\section{References}

1. World Health Organisation Consultation: Definition, diagnosis and classification of diabetes mellitus and its complications. Part 1: diagnosis and classification of diabetes mellitus. Report of a WHO Consultation Geneva; 1999

2. Gupta OP, Phatak S: Pandemic Trends in Prevalence of Diabetes Mellitus and Associated Coronary Heart Disease in India - Their Causes and Prevention. Int I Diabetes Dev Countries 2003, 23:37-50

3. Leena AA, Jill PC: Type 2 Diabetes Prevention: A Review. Clinical Diabetes 2010, 28(2):53-59.

4. Rang HP, Dale MM, Ritter JM, Moore PK: Pharmacology. 5 edition. Churchil Livingstone; 2003, 382.

5. Eichler HG, Korn A, Gasic S, Prison W, Businger J: The effect of new specific a-amylase inhibitor on post-prandial glucose and insulin excursions in normal subjects and Type 2 (non-insulin dependent) diabetic patients. Diabetologia 1984, 26(4):278-281.

6. Tarling CA, Woods K, Zhang R, Brastianos HC, Brayer GD, Andersen RJ, Withers SG: The Search for Novel Human Pancreatic a-Amylase Inhibitors: High-Throughput Screening of Terrestrial and Marine Natural Product Extracts. ChemBioChem 2008, 9:433-438.

7. Cheng AYY, Fantus IG: Oral antihyperglycemic therapy for type 2 diabetes mellitus. Canadian Medicinal Association Journal 2005, 172(2):213-226.

8. Grover JK, Yadav S, Vats V: Medicinal plants of India with anti-diabetic potential. J Ethnopharmacol 2002, 81:81-100

9. Mukherjee PK, Maiti K, Mukherjee K, Houghton PJ: Leads from Indian medicinal plants with hypoglycemic potentials. J Ethnopharmacol 2006, 106(1):1-28

10. Babu PA, Suneetha G, Boddepalli R, Lakshmi W, Rani TS, Rambabu Y, Srinivas K: A database of 389 medicinal plants for diabetes. Bioinformation 2006, 1(4):130-171

11. Farnsworth NR: In Screening plants for new medicines. Edited by: Wilson EO. Biodiversity National Academy Press, Washington DC; 1998:83-97.

12. Elder C: Ayurveda for diabetes mellitus: a review of the biomedical literature. Altern Ther Health Med 2004, 10(1):44-50

13. Chopra RN, Nayar SL, Chopra IC: Glossary of Indian Medicinal Plants Council of Scientific and Industrial Research, ND. India; 1986.

14. WHO: Footnote to Annex 3. WHO Expert Committee on Diabetes Mellitus, 2nd Report. Technical Report Series \#646 WHO; 1980, 9.

15. Creutzfeldt W: Effects of the a-glucosidase Inhibitor Acarbose on the Development of Long-term Complications in Diabetic Animals: Pathophysiological and Therapeutic Implications. Diabetes Metab Res Rev 1999, 15:289-296.

16. Mertes G: Safety and efficacy of acarbose in the treatment of Type 2 diabetes: data from a 5-year surveillance study. Diabetes Research and Clinical Practice 2001, 52:193-204

17. Gupta R, Bajpai KG, Johri S, Saxena AM: An overview of Indian Novel traditional medicinal plants with antidiabetic potentials. Afr J Trad CAM 2008, 5(1):1-17.

18. Tanko Y, Yerima M, Mahdi MA, Yaro AH, Mohammed A: Hypoglycemic Activity of Methanolic Stem Bark of Adansonnia digitata Extract on Blood Glucose Levels of Streptozocin-Induced Diabetic Wistar Rats. International Journal of Applied Research in Natural Products 2008, 1(2):32-36

19. Rizvi MMA, Irshad M, Gamal El Hassadi G, Younis SB: Bioefficacies of Cassia fistula: An Indian labrum. African Journal of Pharmacy and Pharmacology 2009, 3(6):287-292

20. Thakur G, Mitra A, Pal K, Rousseau D: Effect of flaxseed gum on reduction of blood glucose \& cholesterol in Type 2 diabetic patients. Int J Food Sci Nutr 2009, 60(S6):126-136.

21. Ishikawa A, Yamashita H, Hiemori M, Inagaki E, Kimoto M, Okamoto M, Tsuji H, Memon AN, Mohammadi A, Natori Y: Characterization of inhibitors of post prandial hyperglycemia from the leaves of Nerium indicum. Journal of Nutritional Science and Vitaminology 2007, 53:16-173.
22. Brayer GD, Luo Y, Withers SG: The structure of human pancreatic aamylase at $1.8 \mathrm{~A}$ resolution and comparisons with related enzymes. Protein Science 1995, 4:1730-1742.

23. Xiao Z, Storms R, Tsang A: A quantitative starch-iodine method for measuring alpha-amylase and glucoamylase activities. Anal Biochem 2006, 351(1):146-148

24. Miller GL: Use of dinitrosalicylic acid reagent for determination of reducing sugar. Analytical chemistry 1959, 31:426-428.

25. Parekh J, Chanda SV: In vitro Antimicrobial Activity and Phytochemical Analysis of Some Indian Medicinal Plants. Turk J Biol 2007, 31:53-58.

26. Trease GE, Evans WC: Pharmacognsy. 11 edition. Brailliar Tiridel Can. Macmillian publishers; 1989

27. Layer P, Rizza RA, Zinsmeister AR, Carlson GL, DiMagno EP: Effect of a purified amylase inhibitor on carbohydrate tolerance in normal subjects and patients with diabetes mellitus. Mayo Clin Proc 1986, 61(6):442-447.

28. Tundis R, Loizzo MR, Menichini F: Natural products as alpha-amylase and alpha-glucosidase inhibitors and their hypoglycaemic potential in the treatment of diabetes: an update. Mini Rev Med Chem 2010, 10(4):315-331.

29. Mangold HK, Spener F: The cyclopentenyl fatty acids. In 'Lipids and Lipid Polymers in Higher Plants'. Edited by: Tevini M, Lichtenthaler HK. SpringerVerlag, Berlin; 1977:85-101.

30. Sebedio JL, Grandgirard A: Cyclic fatty acids: natural sources, formation during heat treatment, synthesis and biological properties. Progr Lipid Res 1989, 28:303-336

31. Stasevich OV, Mikhalenok SG, Kurchenko VP: Isolation of secoisolariciresinol diglucoside from lignan containing extract of Linum usitatisumum seeds. Chem of Nat Compounds 2009, 45(1):21-23.

32. Bhat M, Zinjarde SS, Bhargava SY, Ravikumar A, Joshi BN: Antidiabetic Indian Plants: A Good Source of Potent Amylase Inhibitors. Evid Based Complement Altern Med 2008

33. Arpornsuwan T, Wetprasit N, Promboon A, Ratanapo S: Antibacterial activity and cytotoxicity of the leaf essential oil of Morus rotunbiloba Koidz. J Med Plant Res 2010, 4(9):837-843.

34. Song W, Wang HJ, Zhang PF, Wei DZ, Lu Y: Phytochemical Profiles of Different Mulberry (Morus sp.) Species from China. J Agric Food Chem 2009, 57(19):9133-9140

35. Vani SR, Cheng SF, Chuah CH: Comparative Study of Volatile Compounds from Genus Ocimum. Am J Appl Sci 2009, 6(3):523-528.

36. Charles DJ, Simon JE, Wood KV: Essential Oil Constituents of Ocimum micranthum Willd. J Agric Food Chem 1990, 30(1):120-122.

37. Vaccarello-Dunkel F, Weaver DK, Weaver TW: Insecticidal or insect behaviourally active preparations from aromatic plants. United States Patent, 5,591,435 1997

38. Chattopadhyay RR: Hypoglycemic effect of Ocimum sanctum leaf extract in normal and streptozotocin diabetic rats. Indian J Exp Biol 1993, 31:891-893.

39. Loizzo MR, Saab AM, Statti GA, Menichini F: Composition and a-amylase inhibitory effect of essential oils from Cedrus libani. Fitoterapia 2007 78(4):323-326

40. Eidia A, Eidib M, Esmaeillia E: Antidiabetic effect of garlic (Allium sativum L.) in normal and streptozotocin-induced diabetic rats. Phytomedicine 2006, 13:624-629.

41. Yagi A, Hegazy S, Kabbash A, Abd-El Wahab E: Possible hypoglycemic effect of Aloe vera L. high molecular weight fractions on Type 2 Diabetic patients. Saudi Pharmaceutical Journal 2009, 17(3):210-218.

42. Nammi S, Boini MK, Lodagala S, Behara RBS: The juice of fresh leaves of Catharanthus roseus Linn. reduces blood glucose in normal and alloxan diabetic rabbits. BMC Compl Alternative Med 2003, 3(4):1-4.

43. Verspohl EJ, Bauer K, Neddermann E: Antidiabetic effect of Cinnamomum cassia and Cinnamomum zeylanicumin vivo and in vitro. Phytother Res 2005, 19(3):203-206.

44. Shibib BA, Khan LA, Rahman R: Hypoglycaemic activity of Coccinia indica and Momordica charantia indiabetic rats: depression of the hepatic gluconeogenic enzymes glucose-6-phosphatase and fructose-1,6bisphosphatase and elevation of both liver and red-cell shunt enzyme glucose-6-phosphate dehydrogenase. Biochem J 1993, 292:267-270.

45. Bhowmik A, Khan LA, Akhter M, Rokeya B: Studies on the antidiabetic effects of Mangifera indica stem-barks and leaves on nondiabetic, type 1 and type 2 diabetic model rats. Bangladesh J Pharmacol 2009, 4:110-114.

46. Mohammadi J, Naik PR: Evaluation of Hypoglycemic effect of Morus alba in an animal model. Indian J of Pharmacoly 2008, 40(1):15-18. 
47. Sethi J, Sood S, Seth S Talwar A: Evaluation of Hypoglycemic and Antioxidant Effect of Ocimum sanctum. Indian J Clin Biochem 2004, 19(2):152-155

48. Kaleem M, Sarmad H, Bano B: Protective Effects of Piper nigrum and Vinca rosea in Alloxan induced Diabetic Rats. Indian J Physiol Pharmacol 2005, 49(1):65-71.

49. Rao NK, Nammi S: Antidiabetic and renoprotective effects of the chloroform extract of Terminalia chebula Retz. seeds in streptozotocininduced diabetic rats. BMC Compl Alternative Med 2006, 6(17):1-6.

50. Singh SS, Pandey SC, Srivastava S, Gupta VS, Patro B, Ghosh AC: Chemistry and Medicinal Properties of Tinospora cordifolia (Guduchi). Indian J of Pharmacol 2003, 3:83-91

51. Ismail MYM: Clinical Evaluation of Antidiabetic Activity of Trigonella Seeds and Aegle marmelos Leaves. World Applied Sciences Journal 2009 7(10):1231-1234

52. Agoreyo FO, Agoreyo BO, Onuorah MN: Effect of aqueous extracts of Hibiscus sabdariffa and Zingiber Officinale on blood cholesterol and glucose levels of rats. Phytother Res 2006, 20:764-772.

Pre-publication history

The pre-publication history for this paper can be accessed here: http://www.biomedcentral.com/1472-6882/11/5/prepub

doi:10.1186/1472-6882-11-5

Cite this article as: $P$ et al:: Potent $\alpha$-amylase inhibitory activity of Indian Ayurvedic medicinal plants. BMC Complementary and Alternative Medicine 2011 11:5

\section{Submit your next manuscript to BioMed Central} and take full advantage of:

- Convenient online submission

- Thorough peer review

- No space constraints or color figure charges

- Immediate publication on acceptance

- Inclusion in PubMed, CAS, Scopus and Google Scholar

- Research which is freely available for redistribution

Submit your manuscript at www.biomedcentral.com/submit 